\title{
Effect of reduced heifer nutrition during in utero and post-weaning development on glucose and acetate kinetics
}

\author{
Richard C. Waterman*, Andrew J. Roberts, Thomas W. Geary, Elaine E. Gringst, Leeson J. Alexander \\ and Michael D. MacNeil \\ Fort Keogh Livestock and Range Research Laboratory, United States Department of Agriculture - Agricultural Research \\ Service, 243 Fort Keogh Road, Miles City, MT 59301, USA
}

(Received 26 October 2010 - Revised 23 March 2011 - Accepted 23 March 2011 - First published online 21 June 2011)

\begin{abstract}
Energetic efficiency was evaluated in composite bred heifers born from dams receiving 1.8 or $1.2 \mathrm{~kg} / \mathrm{d}$ winter supplementation for approximately $80 \mathrm{~d}$ before parturition. Heifers were then developed post-weaning and randomly assigned to heifer development treatments of either control (100\%; ad libitum; $n$ 8/year) or restricted ( $80 \%$; fed $80 \%$ of supplementation fed to controls adjusted to a common body weight: $n$ 8/year) in a 2-year study. A glucose tolerance test (GTT) and acetate irreversible loss test (AILT) were administered to heifers at the termination of a $140 \mathrm{~d}$ development period when the heifers were approximately $403 \mathrm{~d}$ of age and consumed a silage-based diet, and again at $940 \mathrm{~d}$ of age when pregnant with their second calf and grazing dormant forage. No differences were measured $(P>0.08)$ for dam winter nutrition or heifer development treatment for baseline serum metabolites or measures in either the GTT or the AILT. However, changes in baseline serum concentrations $(P>0.05)$ were different between metabolic challenges, which occurred at different stages of development. No difference in acetate disappearance $(P=0 \cdot 18)$ and half-life $(P=0 \cdot 66)$ was measured between the two metabolic challenges. A trend for glucose half-life to be shorter in heifers born from dams receiving in utero winter treatments that supplied $1.2 \mathrm{~kg} / \mathrm{d}$ of winter supplementation was observed $(P=0.083)$. Heifers developed with lower total DM intake during a $140 \mathrm{~d}$ development period had similar glucose and acetate incorporation rates as ad libitum-fed heifers when evaluated at two different production stages.
\end{abstract}

Key words: Acetate irreversible loss test: Feed level: Glucose tolerance test: Harvested feed: Oxidative metabolism: Serum metabolites

A major production expense for beef cow/calf enterprises is associated with the development of replacement heifers and their associated feed inputs ${ }^{(1,2)}$. The present paradigm for the development of replacement heifers implies that heifers need to obtain a certain body weight (BW, 60-65\% of mature weight) and be pubertal by 14 months of age in order to give birth to their first calf by 24 months of age in most North American production systems, while globally other production systems may target a more liberal time frame beyond 24 months of age for heifers to have their first offspring. It is believed by cow/calf producers in the Northern Great Plains, USA, that achievement of this goal requires providing additional feed resources above those provided by native rangelands from weaning to breeding. Appropriate development of replacement heifers is crucial in order to obtain puberty ${ }^{(3-6)}$, promote lifetime productivity and optimise milking ability ${ }^{(7,8)}$. Low nutrient intake following weaning can delay the onset of puberty ${ }^{(4-6,9)}$, while very high levels of nutrition following weaning may reduce lifetime productivity, longevity in a cow herd and limit the milking ability of heifers ${ }^{(7,8)}$. Researchers ${ }^{(10)}$ concluded that producers have many options of developing heifers as long as the necessary weight is achieved by breeding (14 months of age). Therefore, producers encounter the challenge of obtaining reproductive competency (i.e. puberty) in heifers while minimising input (i.e. harvested feedstuffs) costs. However, over the last few decades, it has become evident that the size of mature cow has increased ${ }^{(11,12)}$, which increases nutrient requirements, making it even more difficult to economically feed heifers to achieve the standard BW by breeding. Reports provide evidence that harvested feed inputs can be reduced without sacrificing reproductive performance ${ }^{(1)}$ by targeting a lesser BW (\% of mature BW) for replacement females $^{(13)}$.

Abbreviations: ADEQ, adequate dam winter supplementation; AILT, acetate irreversible loss test; AUC, area under the curve; BW, body weight; GTT, glucose tolerance test; LARRL, livestock and range research laboratory; MARG, marginal dam winter supplementation.

*Corresponding author: R. C. Waterman, fax +1 406874 8289, email richard.waterman@ars.usda.gov

†Present address: International Livestock Research Institute, c/o IITA, PMB 5320, Ibadan, Nigeria. 
To evaluate the metabolic influence of reduced feeding of harvested feedstuffs during the heifer development period, an evaluation of the efficiency of tissue nutrient uptake of specific energetic metabolites can be evaluated (i.e. glucose and acetate). Glucose tolerance tests (GTT) are frequently used to evaluate the efficiency of tissues to incorporate glucose. Hepatic, pancreatic and small intestinal tissues express GLUT2, which is primarily responsible for maintaining homeostatic status of glucose in the normal physiological state. The GLUT2 transporter is insulin independent and in the hepatic tissue regulates excess peripheral glucose by removing it from circulation, while pancreatic $\beta$-cells of the islets of Langerhans along with glucokinase monitor glucose concentrations and may help regulate insulin secretion ${ }^{(14-17)}$. The insulin-dependent GLUT4 found in muscle and adipose tissue $^{(18)}$ is present when higher physiological concentrations of blood glucose are detected ${ }^{(19)}$. Therefore, a GTT that delivers a high physiological dose of glucose can indirectly measure the efficiency of both the GLUT2 (initial response of glucose uptake by hepatic and pancreatic tissues) and more importantly GLUT4 (extended response directed to muscle and adipose via pancreatic insulin release and subsequent tissue responsiveness to insulin), and in the case of the present study evaluate glucose incorporation with regard to heifers fed at two different planes of nutrition and at two different physiological production ages. The question arises is whether animals that are produced from and developed on different planes of dietary intake may become conditioned to have tissues that respond differently to metabolic signals (i.e. insulin). Tissues that are insulin insensitive lack the ability to signal GLUT and have them translocate to tissue cell membranes. In grazing livestock, this can occur when forages senesce and ruminal acetate concentration becomes much greater than propionate ${ }^{(20)}$. Conversely, in ruminants if acetate accumulates from an inadequate supply of glucogenic precursors for hepatic gluconeogenesis, this may exacerbate tissue insulin insensitivity through the production of ketones and NEFA ${ }^{(21-25)}$.

Hepatic ketogenesis occurs at similar rates with no discrimination in fed, non-pregnant, non-lactating goats, sheep and dairy cows, and hepatic tissue release of $\beta$-hydroxybutyrate increases in late gestation and early lactation ${ }^{(26)}$. Acetate irreversible loss tests (AILT) indirectly evaluate the efficiency of energy metabolism in ruminants. Acetate, an endproduct of ruminal fermentation, is a precursor for lipogenesis in adipose tissue, where acetyl-CoA is used to synthesise fat. Acetate is also an intermediate in the tricarboxylic acid cycle, where acetyl-CoA is utilised to regenerate citrate and eventually ATP. Acetate utilisation is dependent upon the supply of intracellular glucose, which is the sum of glucose supply and insulin sensitivity. When the lipogenic pathway (incorporation of acetate into long-chain fatty acids in adipose tissue) and tricarboxylic acid cycle (incorporation of acetate to convert oxaloacetate to citrate) are operating less efficiently, excess acetate is either oxidised as a substrate in futile cycles or directed towards the synthesis of ketones ${ }^{(27,28)}$. Therefore, the rate of irreversible loss or half-life of acetate into peripheral tissues will identify the glucogenic potential of the diet ${ }^{(20)}$ and identify how efficient acetate is being incorporated into lipids and utilised in the tricarboxylic acid pathway since acetate moves into cells passively via the extracellular-intracellular concentration gradient. AILT allows for an indirect measure of the rate of acetate utilisation.

The objective of the present study was to evaluate energy status by comparing glucose and acetate kinetics in maternal tissues by conducting GTT and AILT on heifers born from dams that received two different winter supplementation treatments in utero and then were reared on two post-weaning nutritional development programmes.

\section{Materials and methods}

\section{Study area}

The present study was conducted at the Fort Keogh Livestock and Range Research Laboratory (LARRL) located approximately $1.6 \mathrm{~km}$ west of Miles City, MT, USA $\left(46^{\circ} 22^{\prime} \mathrm{N} 105^{\circ} 5^{\prime} \mathrm{W}\right)$. The LARRL encompasses 22500 ha and has an average elevation of $730 \mathrm{~m}$, which includes rolling hills and barren land with small intersecting streams that drain into large permanent rivers. Precipitation and temperature patterns varied during 2003 through 2006 when the study took place (Fig. 1). Predominant grass genera at study sites include grama (Bouteloua), needlegrass (Hesperostipa) and wheatgrass (Pascopyron) within a mixed grass-dominated rangeland ${ }^{(29)}$.

\section{Herd management}

The LARRL Institutional Animal Care and Use Committee approved all animal handling and experimental procedures used in the present study.

The heifers were a stable composite gene combination population composed of $1 / 2$ Red Angus, 1/4 Charolais and 1/4 Tarentaise. Heifers represent a randomly selected population produced by mating composite dams and sires with consideration given to minimising inbreeding but without emphasis on production traits or dam nutritional treatment. The heifers were born over a 2 -year period from dams that were fed harvested feed from mid-to-late gestation (approximately $80 \mathrm{~d}$ before parturition) that provided an adequate dam winter supplementation (ADEQ) or marginal dam winter supplementation (MARG) level of supplemental nutrition. The ADEQ and MARG treatments were designed to complement dormant protein-deficient forage from nutrient analysis collected on rumen and oesophageal diet extrusa samples (file data at LARRL). In brief, supplemental feed was supplied either daily or every other day to deliver on average $1.8 \mathrm{~kg} / \mathrm{d}$ for each ADEQ cow and $1.2 \mathrm{~kg} / \mathrm{d}$ for each MARG cow. The only exception was during days when access to pasture forage was limited due to snow cover when cows were fed at a rate equivalent to 10.9 or $9.1 \mathrm{~kg}$ alfalfa hay/d for each cow in the ADEQ or MARG treatments, respectively ${ }^{(30)}$. This composite gene combination herd is subjected to a minimum of five cattle handling days per year (pre-calving in early March, pre-breeding in early June, autumn pregnancy check in mid September, weaning in mid-October and 


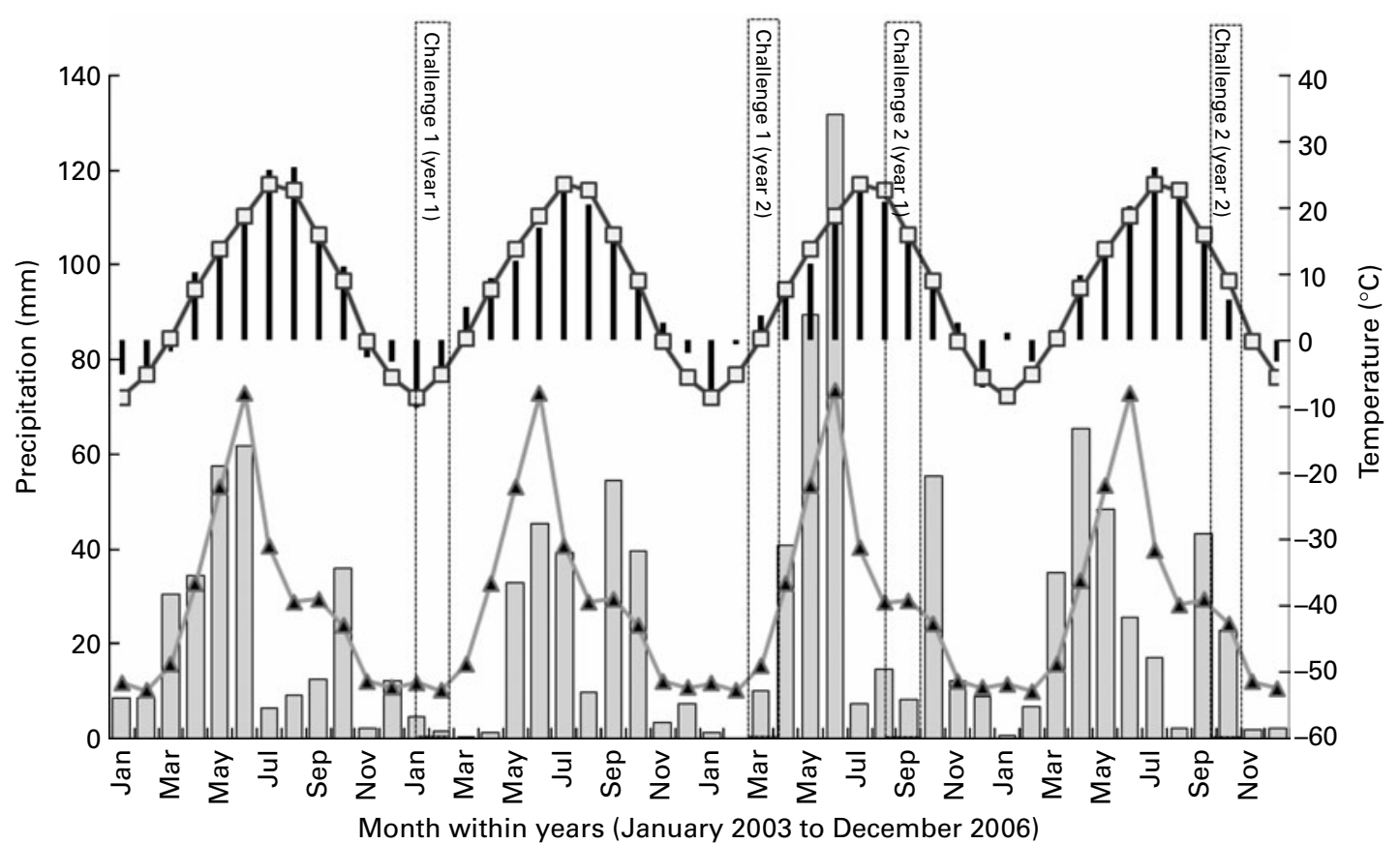

Fig. 1. Monthly precipitation ( $\square$ ) and temperature ( $\square$ ) from January 2003 to December 2006 and their corresponding 69 years average precipitation and temperature ( $\neg-$ precipitation, $-\square-$ temperature) in Miles City, MT, USA. Annual precipitation was $280,240,380$ and $270 \mathrm{~mm}$, respectively, for $2003,2004,2005$ and 2006 with a 69-year average annual precipitation of $340 \mathrm{~mm}$. Initiation of metabolic challenges began in May of each year followed by a second challenge in October of the subsequent year as indicated by dashed lines. Information obtained from Western Regional Climate Center ${ }^{(44)}$ for monthly and historical average annual precipitation and temperature.

allocation to winter treatments in early December), at which time BW and body condition scores are assessed. Body condition scores (1, emaciated and 9, extremely obese) were assigned by two experienced technicians ${ }^{(31,32)}$.

A complete description of the experimental design and protocol has been reported ${ }^{(30,33)}$. In brief, at weaning, the heifers were stratified into groups of six based on weaning weight. Each group was randomly assigned to one of the twentytwo to twenty-four pens. Each pen measures approximately $5.8 \times 11 \mathrm{~m}$ and contains six individual feed stanchions equipped with electronic Calan gates (American Calan, Inc., Northwood, NH, USA) to accommodate individual feed delivery and consumption. The heifers were adapted to the pen environment and mechanical operation of Calan gates for approximately $30 \mathrm{~d}$. During adaptation, the heifers were provided daily ad libitum access to the experimental diet (approximately $10.8 \mathrm{~kg} / \mathrm{d}$; Table 1). The heifers were randomly assigned to either a control (ad libitum; 100\%) or restricted $(80 \%)$ level of feeding within the pens. Control heifers were fed to appetite and $80 \%$ heifers were fed at $80 \%$ of that consumed by $100 \%$ heifers that were adjusted to a common BW basis using the following formula: $(0.80 \times($ mean $\mathrm{BW}$ of restricted/mean $\mathrm{BW}$ of control $) \times$ mean daily feed intake (as-fed basis) of controls over the preceding $28 \mathrm{~d}$ period). Heifer BW was measured every $28 \mathrm{~d}$ throughout the $140 \mathrm{~d}$ development period and feed intake was adjusted using the aforementioned formula.

Orts were removed from the feed bunk and weight was recorded as necessary to ensure that fresh feed was available for each heifer on a daily basis. At the end of the $140 \mathrm{~d}$ development period, the heifers were placed into common pens and received ad libitum feed for an additional $50 \mathrm{~d}$ to allow for oestrous synchronisation and artificial insemination. Synchronisation and artificial insemination protocols have been described ${ }^{(33)}$. Following artificial insemination, the heifers were managed as one herd until gestation/winter

Table 1. Feedstuffs and chemical composition (DM basis) of diets fed during a $140 \mathrm{~d}$ heifer development period in 2004 and 2005

\begin{tabular}{|c|c|c|c|}
\hline \multirow[b]{2}{*}{ Item* } & \multirow[b]{2}{*}{$\begin{array}{c}2004 \\
(\% \text { of DM) }\end{array}$} & \multicolumn{2}{|c|}{$2005(\%$ of $\mathrm{DM})$} \\
\hline & & $\begin{array}{l}\text { First } \\
40 \mathrm{~d}\end{array}$ & Remainder† \\
\hline \multicolumn{4}{|l|}{ Ingredient } \\
\hline Maize silage & 67 & $70 \cdot 9$ & 63.5 \\
\hline Alfalfa hay & 18 & 16 & $20 \cdot 2$ \\
\hline Barley grain & 9 & $7 \cdot 8$ & 9.8 \\
\hline Soyabean meal & 4.2 & 3.7 & 4.6 \\
\hline Urea & 0.9 & 0.8 & 1.0 \\
\hline Calcium carbonate & 0.5 & 0.4 & 0.5 \\
\hline Salt & 0.2 & 0.2 & 0.2 \\
\hline Vitamins $A, D$ and $E \ddagger$ & 0.1 & $0 \cdot 1$ & 0.1 \\
\hline Trace mineral§ & 0.1 & 0.1 & 0.1 \\
\hline \multicolumn{4}{|l|}{ Chemical composition\| } \\
\hline DM (\%) & $36 \cdot 1$ & $41 \cdot 1$ & 32.5 \\
\hline Crude protein (\%) & $15 \cdot 1$ & 14.4 & $15 \cdot 8$ \\
\hline Neutral-detergent fibre (\%) & 39.9 & $40 \cdot 6$ & 39.5 \\
\hline $\begin{array}{l}\text { Net energy for } \\
\text { maintenance }(\mathrm{MJ} / \mathrm{kg})\end{array}$ & 6.56 & 6.56 & 6.56 \\
\hline
\end{tabular}

* Adapted from Roberts et al. ${ }^{(33)}$

$\dagger$ A change in source of silage resulted in slightly different dietary formulation.

\# Contained $13200000 \mu \mathrm{g} / \mathrm{kg}$ of vitamin A, $22000 \mu \mathrm{g} / \mathrm{kg}$ of vitamin D and $396 \mu \mathrm{g} / \mathrm{kg}$ of vitamin $\mathrm{E}$.

$\S$ Contained $20 \% \mathrm{Mg}, 0.2 \% \mathrm{~K}, 2.6 \% \mathrm{~S}, 18000$ parts per million (ppm) of $\mathrm{Cu}$, $60000 \mathrm{ppm}$ of $\mathrm{Zn}, 40000 \mathrm{ppm}$ of $\mathrm{Fe}, 300 \mathrm{ppm}$ of Se, $60000 \mathrm{ppm}$ of $\mathrm{Mn}, 180 \mathrm{ppm}$ of Co and $1140 \mathrm{ppm}$ of $\mathrm{I}$.

|| Based on analysed chemical composition of individual ingredients. 
nutritional treatments were applied. Winter nutritional treatments consisted of separating heifers into two herds ADEQ or MARG - from November through February. At the beginning of March, just before parturition, all first calf heifers were combined and managed as a single herd receiving the same nutritional management regimen until the subsequent winter feeding regimen when they were separated to receive their gestation/winter nutritional treatments.

\section{Experimental animals}

A study initiated in 2001 was designed to investigate the immediate and long-term responses from the offspring of cows permanently assigned to ADEQ or MARG winter nutritional treatments. Each year at weaning, the heifers from the ADEQ and MARG cows are randomly assigned to one of two levels of development (100 or $80 \%$ ) for $140 \mathrm{~d}$ with no discrimination to dam treatment.

A total of thirty-two (16/year; eight heifers assigned from each nutritional programme (100 and $80 \%)$ ) heifers were randomly assigned to receive administration of a GTT and AILT. The heifers used in the present study were born from dams receiving the ADEQ ( $n$ 12) or MARG ( $n$ 20) winter nutritional treatment. The heifers used in year 1 (2003) were born between days 87 and 93 (average day of 91 (SEM 0.4) d; BW 35 (SEM 0.88) kg) and weaned on day 281 (190 (sEm 0.04) d of age; BW 219 (SEM 4.7) kg). The heifers used in year 2 (2004) were born between days 73 and 92 (average day of 83 (SEM 1.5) d; BW 34 (SEM 1.29) kg) and were weaned on day 297 (SEM 214 (SEM 1.5) d of age; 203 (sem 6.3) kg).

\section{Metabolic measures of energetic efficiency}

Heifer BW and body condition score were recorded on the morning of each metabolic test. The heifers were subjected to the first metabolic test in May (before oestrous synchronisation), a GTT (403 (SEM 1.13) d of age) and an AILT (403 (sEM $1 \cdot 13) \mathrm{d}$ of age) at the cessation of the $140 \mathrm{~d}$ development period in both years. In consecutive weeks, one half of 100 and $80 \%$ heifers received a GTT, whereas the remaining heifers received AILT. The following week, the heifers were given the opposite metabolic challenge (GTT or AILT) such that all heifers received both the GTT and the AILT within a $10 \mathrm{~d}$ period. Subsequently, the second metabolic challenge in November (beginning of last trimester of pregnancy), a GTT (935 (sEm 1.50) d of age) and an AILT (945 (sEm 1.71) d of age) were conducted on the same animals the following year during their second pregnancy. For this subsequent evaluation, all heifers received a GTT followed by an AILT $7 \mathrm{~d}$ later.

On the day of the metabolic tests at 06.00 hours (before offering of feed for the May challenge and before morning grazing bout for the November challenge), the heifers were gathered and transported to a cattle-working facility, and fitted with an in-dwelling jugular catheter. Immediately following catheterisation, the heifers were walked, in a low stress manner, to an individual stall located approximately $45 \mathrm{~m}$ adjacent to the chute where in-dwelling jugular catheterisation occurred. The technicians began the metabolic challenges once the heifers were stalled. There was no access to feed or water during the metabolic challenges. For the GTT, a $50 \%(\mathrm{w} / \mathrm{v})$ dextrose solution was infused through the catheter at $0.50 \mathrm{ml} / \mathrm{kg} \mathrm{BW}$ (250 mg glucose $/ \mathrm{kg} \mathrm{BW}$ ) using $60 \mathrm{ml}$ syringes. Blood samples were collected into syringes via a jugular in-dwelling catheter at $-1,0,3,6,9,12,15$, $20,40,60,80,100,120,140,160$ and $180 \mathrm{~min}$ relative to glucose infusion (infusion was immediate after obtaining the 0 min blood sample). During each collection time, $2 \mathrm{ml}$ of blood was initially drawn and discarded to remove saline $(0.9 \% \mathrm{NaCl})$ from the catheter. The blood was then subsequently drawn and transferred from syringes into serum separator tubes $\left(9 \mathrm{ml}\right.$ draw serum separator tubes, Corvac ${ }^{\mathrm{TM}}$; Tyco Healthcare Group LP, Mansfield, MA, USA). A $5 \mathrm{ml}$ saline flush was then pushed through the catheter and the saline syringe remained attached to the catheter until subsequent collection time. The samples were allowed to coagulate and the serum was harvested after centrifugation at $1500 \mathrm{~g}$ for $30 \mathrm{~min}$ and stored at $-20^{\circ} \mathrm{C}$ until analysis.

For AILT, a $20 \%(\mathrm{w} / \mathrm{v})$ acetate solution was infused through the catheter at $1.25 \mathrm{ml} / \mathrm{kg} \mathrm{BW}(4.16 \mathrm{~mm}$ acetate $/ \mathrm{kg} \mathrm{BW})$ using $60 \mathrm{ml}$ syringes. Blood samples were collected into syringes via the jugular in-dwelling catheter at - 1, 0, 1, 3, 5, 7, 10, 15, 30, 60 and $90 \mathrm{~min}$ relative to acetate infusion (infusion was immediately after obtaining the 0 min blood sample). During each collection time, $2 \mathrm{ml}$ blood was initially drawn and discarded to remove saline $(0.9 \% \mathrm{NaCl})$ from the catheter. The blood was then subsequently drawn and transferred from syringes into tubes containing lithium heparin as an additive $\left(7 \mathrm{ml}\right.$ draw, Vacutainer ${ }^{\mathrm{TM}}$; Becton Dickson, Franklin Lakes, NJ, USA). Plasma was collected after being centrifuged at $1500 \mathrm{~g}$ for $30 \mathrm{~min}$ and stored at $-20^{\circ} \mathrm{C}$ until analysis.

To evaluate whether serum metabolite concentrations were influenced by the nutritional regimen, baseline concentrations were evaluated for glucose, insulin, urea-N and NEFA using -1 and 0 pre-infusion samples before the GTT. Additionally, baseline plasma acetate concentrations were measured using -1 and 0 pre-infusion samples before the AILT.

All serum metabolite concentrations were analysed in duplicate aliquots using commercially available kits to measure glucose by the glucose oxidase method (Kit TR15321; Thermo Electron Corporation, Waltham, MA, USA; endpoint with an intra-assay CV of $3.0 \%$ and an inter-assay CV of $5.8 \%$ ), urea $\mathrm{N}$ by the urease method (Kit TR12321; Thermo Electron Corporation; endpoint with an intra-assay $\mathrm{CV}$ of $3.6 \%$ and an inter-assay $\mathrm{CV}$ of $7 \cdot 7 \%$ ) and NEFA by the acyl-CoA synthetaseacyl-CoA oxidase (ACS-ACOD) method (Wako Chemicals USA, Inc., Richmond, VA, USA; endpoint with an intra-assay $\mathrm{CV}$ of $3.2 \%$ and an inter-assay $\mathrm{CV}$ of $1.9 \%$ ). A handheld ketone sensor (MediSence ${ }^{\circledR}$, Precision Xtra ${ }^{\text {TM }}$; Abbott Laboratories, Abbott Park, IL, USA) was used to measure serum $\beta$-hydroxybutyrate ${ }^{(34)}$. Serum insulin concentrations were measured in duplicate by solid-phase ${ }^{125}$ I-Insulin RIA (Coat-a count kit; Diagnostic Products, Inc., Los Angeles, CA, USA). The insulin assay had an intra-assay $\mathrm{CV}$ of $8.8 \%$ and an inter-assay CV of $14.3 \%$ with $99 \%$ recovery. Acetate was filtered by centrifugation with a centrifugal filter device for $2 \mathrm{~h}$ at $5000 \boldsymbol{g}$ for deproteinisation (Millipore Centricon ${ }^{\circledR}$ YM-10 centrifugal 
device; Millipore Corporation, Burlington, MA, USA). The filtered supernatant was mixed in a 5:1 ratio with $25 \%$ meta-phosphoric acid containing $2 \mathrm{~g} / 1$ of 2-ethyl butyric acid as an internal standard. Concentrations of acetate were measured by GC (Thermo Trace GC; Thermo Fisher Scientific, West Palm Beach, FL, USA with a capillary column $(15 \mathrm{~m} \times 0.53 \mathrm{~mm}$; RESTEK Stalbilwax ${ }^{\circledR}$-DA; Bellefonte, PA, USA); temperature ramp $20^{\circ} \mathrm{C} / \mathrm{min}$ from $90^{\circ} \mathrm{C}$ to $220^{\circ} \mathrm{C}$ and maintained for $4 \mathrm{~min}$ ).

Acetate and glucose disappearance, and half-life were estimated for each animal by regression of the logarithmictransformed metabolite concentrations over time ${ }^{(35,36)}$. Total and incremental (i.e. ignores area beneath baseline values) area under the curve (AUC and IAUC, respectively) was determined for acetate, glucose and insulin concentrations using trapezoidal summation.

\section{Statistical analysis}

Data were analysed using the MIXED procedure of the Statistical Analysis Systems statistical software package version 9.1 (SAS Institute, Inc., Cary, NC, USA). A completely randomised block design was used, where a block represented calves born in 2003 and 2004 as follows: calves born in 2003 received metabolic challenges in 2004 and 2005; calves born in 2004 received metabolic challenges in 2005 and 2006. The statistical model included fixed effects of dam winter nutritional treatment (the in utero winter nutritional treatment; ADEQ and MARG), heifer development treatment (100 and 80\%), metabolic challenge (immediately after the heifer development period and when gestating their second calf) and their interactions (i.e. dam winter nutritional treatment $\times$ heifer development treatment; dam winter nutritional treatment $\times$ metabolic challenge; heifer development treatment $\times$ metabolic challenge; dam winter nutritional treatment $\times$ heifer development treatment $\times$ metabolic challenge). Only significant $P \leq 0.05$ interactions are reported. The RANDOM statement included heifer within block $\times$ heifer treatment $\times$ dam treatment. Average daily gain from birth to weaning was calculated and used as a covariate in the model. A total of four heifers each year failed to conceive or calve and were eliminated from the analysis for the second metabolic challenge. Values are expressed as means with standard errors and a $P \leq 0.05$ separating means was considered significantly different.

\section{Results}

\section{Body weight and condition}

BW was similar for dam winter nutritional treatment $(P=0.53)$ and tended to be greater $(P=0.076)$ throughout the study for 100 v. $80 \%$ treated heifers; however, as the heifers aged, BW increased from the first to the second metabolic challenge $(P<0.001 ;$ Table 2). The body condition score was similar for the dam winter nutritional treatment $(P=0 \cdot 86)$. A heifer treatment $\times$ age at metabolic challenge interaction was observed for the body condition score $(P=0.053)$, which indicated that $100 \%$ treated heifers lost body condition as age increased between the metabolic challenges, whereas $80 \%$ treated heifers maintained the same condition (4.5-4.0 (SEM

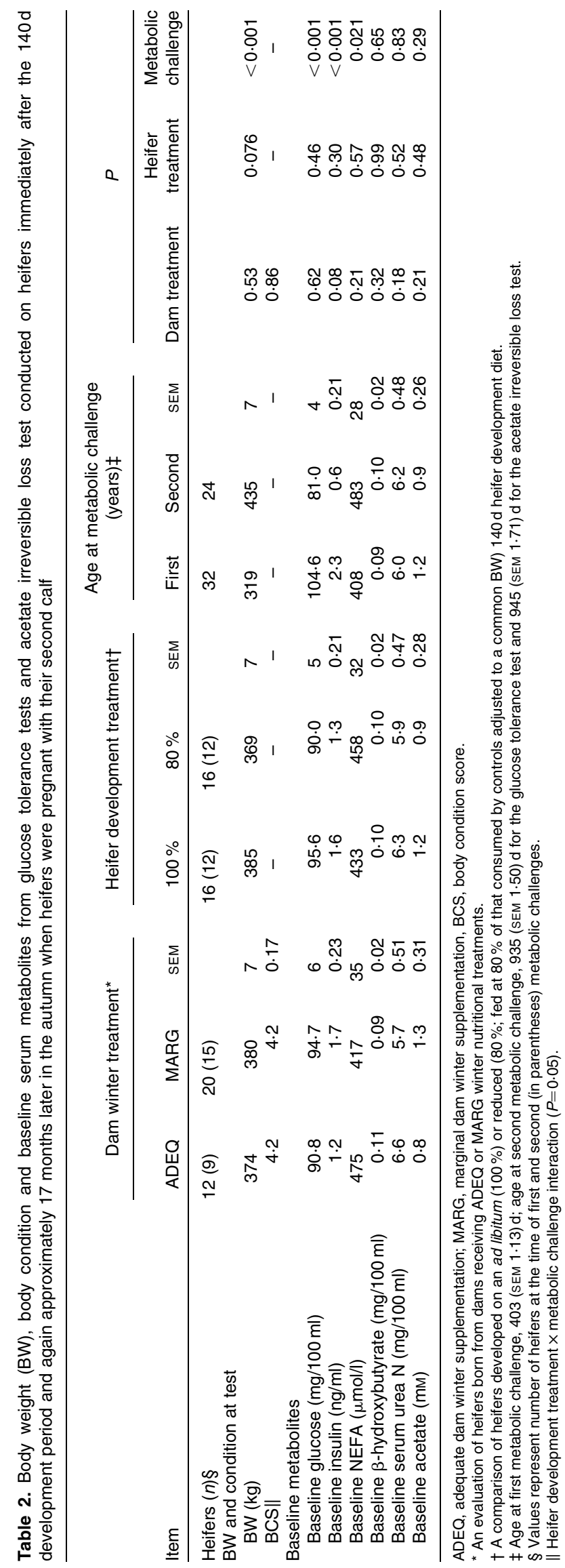


$0 \cdot 17) v \cdot 4 \cdot 1-4 \cdot 2(\operatorname{SEM} 0 \cdot 19)$, respectively, for 100 and $80 \%$ heifer development treatments for age at the first and second metabolic challenges; Table 2).

\section{Baseline metabolites}

Baseline serum glucose concentrations were similar for dam winter nutritional treatment $(P=0.62)$ and heifer development treatment $(P=0.46$; Table 2$)$. There was a $22.6 \%$ decrease in baseline glucose concentrations as age between the metabolic challenges increased $(P<0 \cdot 001)$. Baseline serum insulin concentrations tended to be greater $(P=0.08)$ for dam winter nutritional treatment when the heifers were born from MARG dams compared with the heifers born from ADEQ dams. However, baseline insulin concentrations did not differ due to heifer development treatment $(P=0 \cdot 30)$. Similar to baseline glucose concentrations, there was a $73.9 \%$ decrease $(P<0.001)$ in baseline insulin concentrations as age at metabolic challenge increased (Table 2).

Baseline serum NEFA concentrations were similar for dam winter nutritional treatment $(P=0 \cdot 21)$ and heifer development treatment $(P=0.57)$. Serum NEFA concentrations increased $(P<0.001)$ by $15.5 \%$ as age increased from the first to the second metabolic challenge. Baseline serum $\beta$-hydroxybutyrate concentrations were similar for dam winter nutritional treatment $(P=0.32)$, heifer development treatment $(P=0.99)$ and age at metabolic challenge $(P=0.65)$. Baseline serum urea $\mathrm{N}$ concentrations were similar for dam winter nutritional treatment $(P=0 \cdot 18)$, heifer development treatment $(P=0.52)$ and age at metabolic challenge $(P=0 \cdot 83)$. Baseline serum acetate concentrations were also similar for dam winter nutritional treatment $(P=0 \cdot 21)$, heifer development treatment $(P=0 \cdot 48)$ and age at metabolic challenge $(P=0 \cdot 29$; Table 2$)$.

\section{Response to glucose tolerance test}

The mean profiles of glucose and insulin relative to the infusion of glucose or acetate at the first metabolic challenge when the heifers averaged $403 \mathrm{~d}$ of age and again at the second metabolic challenge when the heifers averaged $935 \mathrm{~d}$ of age are presented in Fig. 2. Peak glucose concentrations, following a bolus dose of glucose, were similar for dam winter nutritional treatments $(P=0.99)$, heifer treatments $(P=0.88)$ and age at metabolic challenges $(P=0.83)$. A dam winter nutritional treatment $\times$ age at metabolic challenge interaction was observed for time to peak glucose concentration $(P=0.008)$. Heifers from dams receiving the ADEQ winter treatment had peak glucose concentration that did not differ for age at the first and second metabolic challenges (3.1-3.6 (SEm 0.68) min), whereas time to peak glucose concentration for heifers from MARG winter-treated dams was shortened as heifer age increased from the first to second metabolic challenge (5.6-3.1 (SEM 0.51) min). Time to peak glucose concentration after infusion was similar for heifer development treatments $(P=0.99$; Table 3$)$. Peak insulin concentrations were similar for dam winter nutritional treatments $(P=0.45)$ and heifer development treatment $(P=0.63)$. However, peak insulin concentrations decreased $(P<0.001)$ by $67 \%$ between the metabolic challenges as the age of the heifers increased from the first to second metabolic challenge. Time to peak insulin concentration after glucose infusion was similar for dam winter nutritional treatment $(P=0.96)$, heifer development treatment $(P=0 \cdot 16)$ and metabolic challenge $(P=0 \cdot 18$; Table 3$)$.

The disappearance of glucose from peripheral circulation was similar between dam winter nutritional treatments $(P=0.39)$, heifer development treatments $(P=0.86)$ and age at metabolic challenges $(P=0 \cdot 13)$. Heifers born from MARG dams tended to have a $24.8 \%$ shorter $(P=0.083)$ glucose half-life than heifers born from ADEQ dams. Glucose halflife did not differ for heifer development treatments $(P=0.34)$ or age at metabolic challenges $(P=0.65)$. Glucose AUC (total and incremental) for glucose following the GTT was similar for dam winter nutritional treatments $(P=0 \cdot 40)$ and heifer treatments $(P=0.53)$. Additionally, total glucose AUC tended $(P=0.066)$ to be lesser during the second metabolic challenge when the heifers were pregnant with their second calf compared with immediately after the heifer development period. Total and incremental insulin AUC did not differ for dam winter nutritional treatments $(P=0.49)$ or heifer treatments $(P=0.32$; Table 3$)$. Both total and incremental insulin AUC were lesser $(P<0.001)$ during the second metabolic challenge when the heifers were pregnant with their second calf compared with immediately after the heifer development period (Table 3).

\section{Responses from the acetate irreversible loss test}

The mean profiles of plasma acetate relative to the infusion of acetate during the AILT at the first metabolic challenge when the heifers averaged $403 \mathrm{~d}$ of age and again at the second metabolic challenge when the heifers averaged $945 \mathrm{~d}$ of age are presented in Fig. 2. A dam winter nutritional treatment $\times$ age at metabolic challenge interaction was measured $(P=0.004)$ for peak acetate concentration and indicated that heifers born from ADEQ dams had decreased acetate concentrations (12.7-6.8 (SEM 1.75) $\mathrm{mm}$ ) as age increased between the first and second metabolic challenges, whereas heifers born from MARG dams had increased acetate concentrations as age increased from the first to second metabolic challenge (6.6-10.5 (SEM 1.30) mm). Peak acetate concentration following acetate infusion was not different for heifer development treatments $(P=0.84)$. Time to peak acetate concentration after infusion was similar for dam winter nutritional treatments $(P=0.80)$ and heifer development treatments $(P=0.59)$ However, as age increased from the first to second metabolic challenge, time to peak acetate concentration was $2.7 \mathrm{~min}$ earlier ( $P=0.003$; Table 3$)$.

Acetate disappearance, half-life and total AUC were similar for dam winter nutritional treatments $(P \geq 0 \cdot 22)$, heifer development treatments $(P \geq 0.62)$ and age at metabolic challenges $(P \geq 0 \cdot 28$; Table 3). A dam winter nutritional treatment $\times$ age at metabolic challenge interaction $(P=0.02)$ for incremental acetate AUC was observed. Heifers from dams receiving the ADEQ winter treatment had incremental acetate AUC that declined as age increased from the first to second metabolic challenge (220-131 (SEM 51) mM $\times 90 \mathrm{~min}$, respectively), 

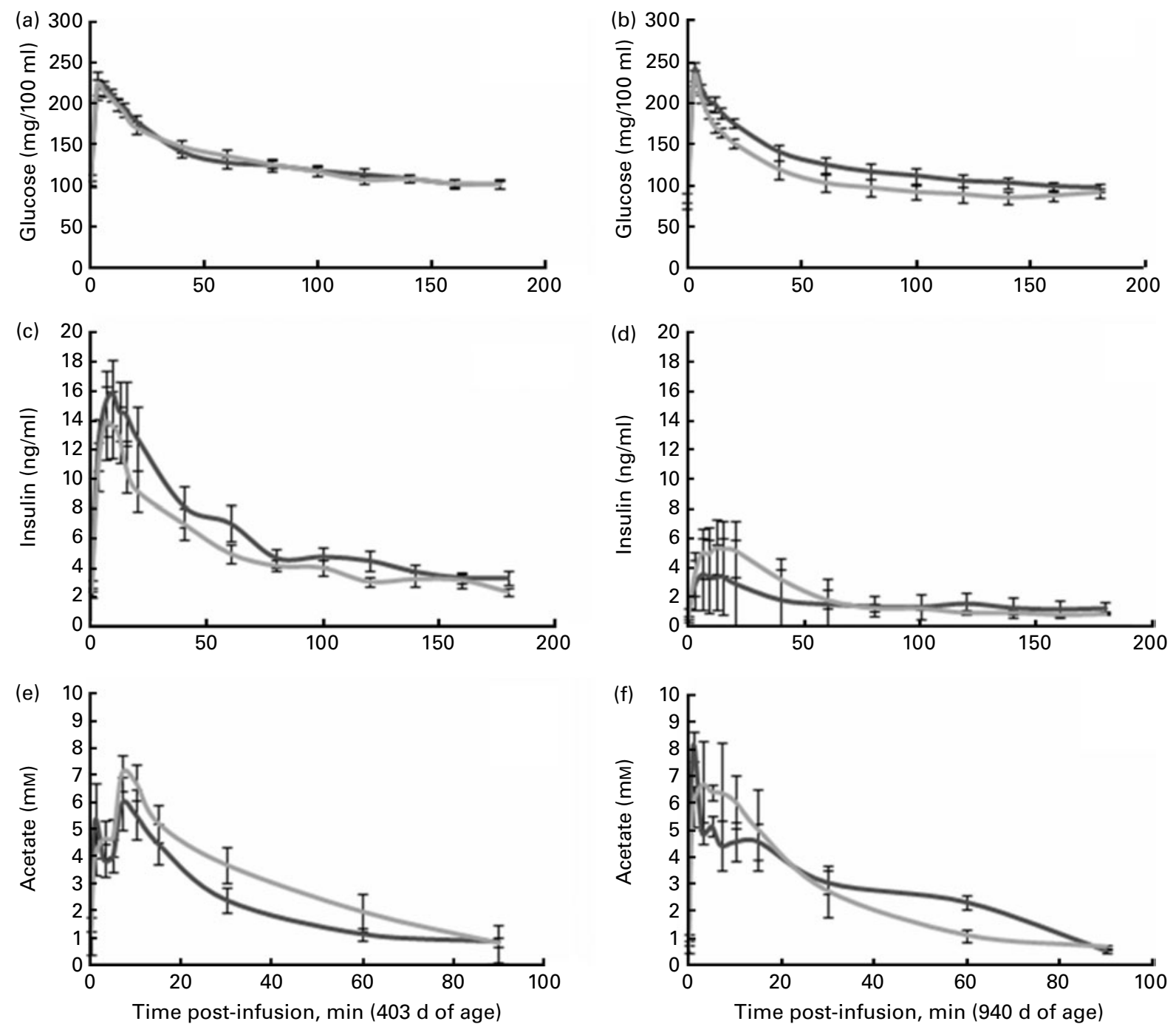

Fig. 2. Mean response profile of ( $a$ and b) glucose, (c and d) insulin and (e and f) acetate of heifers whose dams received either 1.8 or $1.2 \mathrm{~kg} / \mathrm{d}$ of winter nutritional supplementation, and then were developed post-weaning at either ad libitum (100\%, - ) or $80 \%\left(-{ }_{-}\right)$of the ad libitum feed (on a common body weight bases), receiving a glucose (250 mg D-glucose/kg body weight (BW)) and an acetate (4.16 mM acetate/kg BW) tolerance test at $403 \mathrm{~d}$ of age (a, c and e) and again at 935 (SEM 1.50) $d$ of age for the glucose tolerance test and 945 (SEM 1.71) $d$ of age for the acetate irreversible loss test (b, $d$ and f).

whereas incremental acetate AUC for heifers from MARG winter-treated dams increased as heifer age increased from the first to second metabolic challenge (94-220 (SEM 38) mM $\times 90 \mathrm{~min}$, respectively). Additionally, a heifer development treatment $\times$ age at metabolic challenge interaction $(P=0.04)$ for incremental acetate AUC was observed. Heifers receiving the $100 \%$ development treatment had incremental acetate AUC that increased as age increased from the first to second metabolic challenge (108-218 (SEM 42) mm $\times 90 \mathrm{~min}$, respectively), whereas incremental acetate AUC for heifers that received the $80 \%$ development treatment declined as heifer age increased from the first to second metabolic challenge (205-133 (SEM 47) $\mathrm{mm} \times 90 \mathrm{~min}$, respectively).

\section{Discussion}

Post-weaning development of heifers on the restricted protocol results in a $27 \%$ reduction in the use of harvested feed throughout the $140 \mathrm{~d}$ development period $^{(33,37)}$. This resulted in an approximate savings of US\$21 per pregnant heifer ${ }^{(37)}$. Additionally, previous results of heifers in this long-term experiment have consistently shown lesser average daily gain (ADG) and BW gain for $80 \%$ treated heifers compared with $100 \%$ treated heifers beginning approximately 4 weeks after the initiation of the $140 \mathrm{~d}$ heifer development period ${ }^{(33,37)}$. However, ADG from the conclusion of the $140 \mathrm{~d}$ development period through 19.5 months of age was greater for $80 \%$ treated heifers, which indicates a period of compensatory gain and potential metabolic efficiency following reduction in feed $^{(33)}$. The present study represents a small subset of heifers described in previous reports. In agreement with previous reports, heifers that received $100 \%$ treatment weighed more than heifers receiving $80 \%$ treatment at both 403 and $940 \mathrm{~d}$ of age when the metabolic challenges were administered. When management purposely reduced nutrient intake by $20 \%$ of what ad libitum (100\%) treated heifers received (on a common BW basis) during the $140 \mathrm{~d}$ development period, 
Table 3. Peak concentrations, disappearance, half-life and total and incremental area under the curve (AUC and IAUC, respectively) for a glucose tolerance tests and acetate irreversible loss test conducted on heifers immediately after the $140 \mathrm{~d}$ development period and again approximately 17 months later in the autumn when heifers were pregnant with their second calf

\begin{tabular}{|c|c|c|c|c|c|c|c|c|c|c|c|c|}
\hline \multirow[b]{2}{*}{ Item } & \multicolumn{3}{|c|}{ Dam winter treatment ${ }^{*}$} & \multicolumn{3}{|c|}{ Heifer development treatment $†$} & \multicolumn{3}{|c|}{$\begin{array}{l}\text { Age at metabolic challenge } \\
\text { (years) } \ddagger\end{array}$} & \multicolumn{3}{|c|}{$P$} \\
\hline & ADEQ & MARG & SEM & $100 \%$ & $80 \%$ & SEM & First & Second & SEM & $\begin{array}{c}\text { Dam } \\
\text { treatment }\end{array}$ & $\begin{array}{l}\text { Heifer } \\
\text { treatment }\end{array}$ & $\begin{array}{l}\text { Metabolic } \\
\text { challenge }\end{array}$ \\
\hline Heifers $(n) \S$ & $12(9)$ & $20(15)$ & & $16(12)$ & $16(12)$ & & 32 & 24 & & & & \\
\hline \multicolumn{13}{|l|}{ Glucose tolerance test } \\
\hline Peak glucose $(\mathrm{mg} / 100 \mathrm{ml})$ & 238 & 238 & 7 & 239 & 238 & 6 & 237 & 239 & 6 & 0.99 & 0.88 & 0.83 \\
\hline Peak glucose time $(\min ) \|$ & - & - & - & 3.9 & 3.9 & 0.44 & - & - & - & - & 0.99 & - \\
\hline Peak insulin (ng/ml) & 9.5 & 11.6 & $2 \cdot 15$ & $11 \cdot 2$ & 9.9 & 1.96 & $15 \cdot 9$ & $5 \cdot 1$ & 1.76 & 0.45 & 0.63 & $<0.001$ \\
\hline Peak insulin time (min) & 11.7 & 11.8 & $2 \cdot 37$ & 13.9 & $9 \cdot 6$ & $2 \cdot 16$ & 9.9 & $13 \cdot 6$ & $2 \cdot 12$ & 0.96 & 0.16 & 0.18 \\
\hline Glucose disappearance (\%/min) & 1.4 & 1.5 & 0.15 & 1.4 & 1.5 & 0.13 & 1.3 & 1.6 & 0.13 & 0.39 & 0.86 & $0 \cdot 13$ \\
\hline Glucose $t_{1 / 2}(\mathrm{~min})$ & 72.9 & $54 \cdot 8$ & 8 & $59 \cdot 1$ & 68.5 & 7 & $62 \cdot 0$ & 65.6 & 7 & 0.083 & 0.34 & 0.65 \\
\hline Glucose AUC $((\mathrm{mg} / 100 \mathrm{ml}) \times 180 \mathrm{~min})$ & 23581 & 22247 & 1329 & 23400 & 22428 & 1207 & 23621 & 22208 & 931 & 0.45 & 0.56 & 0.066 \\
\hline Glucose IAUC $((\mathrm{mg} / 100 \mathrm{ml}) \times 180 \mathrm{~min})$ & 6447 & 5444 & 911 & 5586 & 6304 & 830 & 5039 & 6852 & 853 & 0.40 & 0.53 & 0.12 \\
\hline Ins AUC $((\mathrm{ng} / \mathrm{ml}) \times 180 \mathrm{~min})$ & 631 & 707 & 85 & 722 & 616 & 77 & 1019 & 319 & 75 & 0.49 & 0.32 & $<0.001$ \\
\hline Ins IAUC ((ng/ml) × $180 \mathrm{~min})$ & 418 & 405 & 69 & 435 & 388 & 63 & 610 & 213 & 65 & 0.89 & 0.59 & $<0.001$ \\
\hline \multicolumn{13}{|l|}{ Acetate irreversible loss test } \\
\hline Peak acetate $(\mathrm{mm}) \|$ & - & - & - & $9 \cdot 28$ & 9.00 & 1.05 & - & - & - & - & 0.84 & - \\
\hline Peak time (min) & 3.85 & 4.46 & 1.33 & 4.68 & 3.63 & $1 \cdot 21$ & 5.47 & $2 \cdot 84$ & 0.95 & 0.73 & 0.53 & 0.004 \\
\hline Acetate disappearance $(\% / \mathrm{min})$ & 3.49 & 4.02 & 0.37 & 3.70 & 3.81 & 0.34 & 4.05 & 3.46 & 0.34 & 0.28 & 0.81 & 0.18 \\
\hline Acetate $t_{1 / 2}(\mathrm{~min})$ & 23.08 & $24 \cdot 15$ & 4 & 24.99 & $22 \cdot 23$ & 3 & 22.72 & 24.51 & 3 & 0.82 & 0.54 & 0.66 \\
\hline Acetate AUC $((\mathrm{mM}) \times 90 \mathrm{~min})$ & 241.5 & 224.6 & 32 & $235 \cdot 0$ & $230 \cdot 0$ & 30 & $240 \cdot 9$ & 224.0 & 31 & 0.71 & 0.90 & 0.68 \\
\hline
\end{tabular}

ADEQ, adequate dam winter supplementation; MARG, marginal dam winter supplementation.

An evaluation of heifers born from dams receiving $A D E Q$ or MARG winter nuplion

† A comparison of heifers developed on an ad libitum ( $100 \%$ ) or reduced ( $80 \%$; fed at $80 \%$ of that consumed by controls adjusted to a common body weight) $140 \mathrm{~d}$ heifer development diet.

¥ Age at the first metabolic challenge, 403 (SEM 1.13) d; age at the second metabolic challenge, 935 (SEM 1.50) d for the glucose tolerance test and 945 (SEM 1.71) d for the acetate irreversible loss test.

Values represent number of heifers at time of the first and second (in parentheses) metabolic challenges.

Dam winter nutritional treatment $\times$ age at metabolic challenge $(P \leq 0.008)$ 
baseline serum metabolite concentrations were unchanged $(P>0 \cdot 10$; Table 2$)$. Serum glucose, insulin, NEFA, urea $\mathrm{N}$ or acetate concentrations remained consistent, even though a lower DM intake was imposed (by experimental design) for the $80 \%$ group $^{(33)}$. Furthermore, 100 and $80 \%$ treated heifers were similar in all measures for GTT and AILT, which suggests that both 100 and $80 \%$ treated heifers have similar rates of gluconeogenesis, insulin sensitivity and release and utilisation of acetate for oxidative metabolism and lipogenesis ${ }^{(38-40)}$. Our data do not reveal any potential mechanism for compensatory gain observed in $80 \%$ treated heifers following the $140 \mathrm{~d}$ heifer development period as reported ${ }^{(33)}$

Researchers ${ }^{(20)}$ have demonstrated that when the glucogenic potential of a diet is low and glucose precursors are added to the diet, acetate irreversible loss is faster and glucose half-life is shorter ${ }^{(24)}$. The present study documents that a reduction in DM intake during a $140 \mathrm{~d}$ development period does not have any detrimental impact on glucose supply, insulin release or tissue sensitivity of acetate utilisation in $80 \%$ treated heifers compared with $100 \%$ treated heifers.

However, differences were measured due to changes in age and physiological state between the two metabolic challenges that were separated by 17 months. Lower pre-infusion (i.e. baseline) concentrations of glucose and insulin from the first and second metabolic challenges partially reflect the diet quality changes that occurred. At the time of the first metabolic challenge, the heifers had completed a $140 \mathrm{~d}$ development trial while consuming a high-quality maize silage-based diet in confinement, whereas the second metabolic challenge that occurred approximately 17 months later when the heifers were consuming mostly dormant rangeland native forages. In ewes, the peripheral concentration of insulin and glucose-stimulated insulin release decreased as gestation advanced $^{(36)}$, and in cattle, both season or quality of forage and physiological state (gestation) have shown decreased responses in glucose uptake and insulin responsiveness ${ }^{(41)}$. Differences in diet quality between the metabolic challenges also explain the greater NEFA concentrations observed during the second metabolic challenges due to likely mobilisation of adipose storage. The serum metabolite concentrations observed at the second metabolic challenge are comparable with concentrations previously reported for cattle grazing dormant rangelands ${ }^{(41)}$. Interestingly, the peak insulin concentration and insulin AUC in the second GTT (in November when the heifers are grazing dormant forages) were substantially lower than those measured in the first GTT (Fig. 2). This may indicate that the pancreatic release of insulin was greater in heifers at the termination of the $140 \mathrm{~d}$ heifer development period and the infusion of glucose was accompanied by a longer sustained pancreatic release of insulin at the first metabolic challenge.

The glucogenic potential of the diet during the second metabolic challenge should have been lower when the heifers were grazing dormant rangelands. Therefore, it would be expected that a higher ruminal acetate:propionate ratio would be observed when the ruminants graze rangelands ${ }^{(42)}$ compared with the maize silage-based diets consumed during the $140 \mathrm{~d}$ heifer development period. From this scenario, a slower acetate irreversible loss could be expected if precursors for gluconeogenesis were limiting ${ }^{(20,38,43)}$. However, differences in acetate irreversible loss from approximately $403 \mathrm{~d}$ of age to $940 \mathrm{~d}$ age were not realised. Previous research $^{(41)}$ has demonstrated that energetic efficiency can be altered due to season and quality of forage being consumed. If any changes in acetate irreversible loss were occurring, it did not alter due to dam winter nutrition or heifer development treatment in the present study.

Potential existed for heifers to differ in glucose and acetate irreversible loss due to carry-over effects from fetal development due to nutritional management treatments imposed on their dams. Since no differences were detected, this would indicate that potential in utero effects did not carry over later in life. A trend $(P=0.083)$ for the glucose half-life to be shorter for heifers calved from MARG dams needs to be further investigated because it could potentially lead to a limited explanation for improved energy efficiency (Table 3).

In conclusion, heifers receiving a $20 \%$ reduction in winter feed provision have comparable indicators of energetic efficiency as heifers that were fed to appetite. This outcome was consistent at both the termination of a $140 \mathrm{~d}$ development period and again approximately 17 months later when the heifers were pregnant with their second calf. These results support other production findings ${ }^{(33,37)}$ that there are opportunities to reduce the amount of harvested feed fed and associated input costs while maintaining sustainable production. Future research may conclude that further reduction in harvested feed inputs may be attainable, which will not only lower overall production costs but also optimise economic feasibility.

\section{Acknowledgements}

The present study was funded by the United States Department of Agriculture, Agricultural Research Service (Project no. 5434-31000-014-00D). The United States Department of Agriculture, Agricultural Research Service, Northern Plains Area, is an equal opportunity/affirmative action employer. All agency services are available without discrimination. The present study was conducted under a cooperative agreement between the United States Department of Agriculture, Agricultural Research Service and the Montana Agricultural Experiment Station. Mention of a proprietary product does not constitute a guarantee or warranty of the product by the United States Department of Agriculture, Montana Agricultural Experiment Station or the authors, and does not imply its approval to the exclusion of other products that also may be suitable. R. C. W., A. J. R., T. W. G., E. E. G., L. J. A. and M. D. M. designed the study; R. C. W., A. J. R., T. W. G., E. E. G. and L. J. A. conducted the study; R. C. W. wrote the manuscript; R. C. W. and A. J. R. had primary responsibility for the final content. All authors read and approved the final manuscript. R. C. W. gratefully acknowledges W. Kelly, S. Reil, S. Bellows, B. Shipp, K. Neary, M. Woods, D. Armstrong, C. R. Harris, D. Phelps, T. Mott, R. J. Hubbard, M. Landers and H. Stroh for their technical assistance. The authors declare that there are no conflicts of interest. 


\section{References}

1. Freetly HC, Ferrell CL \& Jenkins TG (2001) Production performance of beef cows raised on three different nutritionally controlled heifer development programs. J Anim Sci 79, 819-826.

2. Clark RT, Creighton KW, Patterson HH, et al. (2005) Symposium paper: economic and tax implications for managing beef replacement heifers. Prof Anim Sci 21, 164-173.

3. Ferrell CL (1982) Effects of postweaning rate of gain on onset of puberty and productive performance of heifers of different breeds. J Anim Sci 55, 1272-1283.

4. Arije GF \& Wiltbank JN (1971) Age and weight at puberty in Hereford heifers. J Anim Sci 33, 401-406.

5. Wiltbank JN, Gregory KE, Swinger LA, et al. (1966) Effects of heterosis on age and weight at puberty in beef heifers. J Anim Sci 25, 744-751.

6. Short RE \& Bellows RA (1971) Relationships among weight gains, age at puberty and reproductive performance in heifers. J Anim Sci 32, 127-131.

7. Pinney DO, Stephens DF \& Pope LS (1972) Lifetime effects of winter supplemental feed level and age at first parturition on range beef cows. J Anim Sci 34, 1067-1074.

8. Swanson EW (1960) Effect of rapid growth with fattening of dairy heifers on their lactational ability. J Dairy Sci $\mathbf{4 3}$, 377-387.

9. Clanton DC \& Zimmerman DR (1970) Symposium on pasture methods for maximum production in beef cattle: protein and energy requirements for female beef cattle. J Anim Sci 30, $122-132$.

10. Clanton DC, Jones LE \& England ME (1983) Effect of rate and time of gain after weaning on the development of replacement beef heifers. J Anim Sci 56, 280-285.

11. Arango JA, Cundiff LV \& Van Vleck LD (2002) Breed comparisons of Angus, Brahman, Hereford, Pinzgauer, Sahiwal, and Tarentaise for weight, weight adjusted for condition score, height, and body condition score. J Anim Sci 80, 3142-3149.

12. Dib MG, Van Vleck LD \& Spangler ML (2010) Genetic analysis of mature size in American angus cattle. Nebraska Beef Cattle Report 29-30.

13. Funston RN \& Deutscher GH (2004) Comparison of target breeding weight and breeding date for replacement beef heifers and effects on subsequent reproduction and calf performance. J Anim Sci 82, 3094-3099.

14. Hughes SD, Quaade C, Johnson JH, et al. (1993) Transfection of AtT-20ins cells with GLUT-2 but not GLUT-1 confers glucose-stimulated insulin secretion. Relationship to glucose metabolism. J Biol Chem 268, 15205-15212.

15. Newgard CB (1994) Cellular engineering and gene therapy strategies for insulin replacement in diabetes. Diabetes $\mathbf{4 3}$, 341-350.

16. Lachaal M, Spangler RA \& Jung CY (1993) High Km of GLUT2 glucose transporter does not explain its role in insulin secretion. Am J Physiol Endocrinol Metab 265, E914-E919.

17. Antoine B, Lefrancois-Martinez AM, Le Guillou G, et al. (1997) Role of the GLUT 2 glucose transporter in the response of the L-type pyruvate kinase gene to glucose in liver-derived cells. J Biol Chem 272, 17937-17943.

18. Hocquette J-F, Castiglia-Delavaud C, Graulet B, et al. (1997) Weaning marginally affects glucose transporter (GLUT4) expression in calf muscles and adipose tissues. Br J Nutr $\mathbf{7 8}, 251-271$.

19. Roche JR, Sheahan AJ, Chagas LM, et al. (2008) Short Communication: change in plasma ghrelin in dairy cows following an intravenous glucose challenge. J Dairy Sci 91 1005-1010.

20. Cronje PB, Nolan JV \& Leng RA (1991) Acetate clearance rate as a potential index of the availability of glucogenic precursors in ruminants fed on roughage-based diets. Br J Nutr $\mathbf{6 6}$ 301-312.

21. Dresner A, Laurent D, Marcucci M, et al. (1999) Effects of free fatty acids on glucose transport and IRS-1-associated phosphatidylinositol 3-kinase activity. J Clin Invest 103, 253-259.

22. Schmitz-Peiffer C, Craig DL \& Biden TJ (1999) Ceramide generation is sufficient to account for the inhibition of the insulin-stimulated PKB pathway in C2C12 skeletal muscle cells pretreated with palmitate. J Biol Chem 274, 24202-24210.

23. Tardif A, Julien N, Pelletier A, et al. (2001) Chronic exposure to beta-hydroxybutyrate impairs insulin action in primary cultures of adult cardiomyocytes. Am J Physiol Endocrinol Metab 281, E1205-E1212.

24. Waterman RC, Sawyer JE, Mathis CP, et al. (2006) Effects of supplements that contain increasing amounts of metabolizable protein with or without Ca-propionate salt on postpartum interval and nutrient partitioning in young beef cows. J Anim Sci 84, 433-446.

25. Waterman RC \& Butler WR (2010) Metaboic signals of the beef cow in negative energy balance. In Proceedings of 4th Grazing Livestock Nutrition Conference, vol. 61, pp. 93-101 [BW Hess, T DelCurto and JGP Bowman, et al., editors]. Champaign, IL: Western Section, American Society of Animal Science.

26. Heitmann RN, Dawes DJ \& Sensenig SC (1987) Hepatic ketogenesis and peripheral ketone body utilization in the ruminant. J Nutr 117, 1174-1180.

27. Armentano LE (1992) Ruminant hepatic metabolism of volatile fatty acids, lactate and pyruvate. J Nutr 122, 838-842.

28. MacRae JC \& Lobley GE (1982) Some factors which influence thermal energy losses during the metabolism of ruminants. Livest Prod Sci 9, 447-456.

29. Küchler AW (1964) Manual to Accompany the Map, Potential Natural Vegetation of the Conterminous United States. Special Publication no. 36. New York: American Geographical Society.

30. Roberts AJ, Waterman RC, Geary TW, et al. (2010) Level of maternal winter supplement and feed restriction during postweaning developmnet influences circulating concentrations of IGF-I in heifers during the peripartum and rebreeding period. Proc West Sec Am Soc Anim 61, 194-196.

31. Herd DH \& Sprott LR (1986) Body condition, nutrition and reproduction of beef cows. Texas Agric Ext Serv B-1526, $1-11$.

32. Wagner JJ, Lusby KS, Oltjen JW, et al. (1988) Carcass composition in mature Hereford cows: estimation and effect on daily metabolizable energy requirement during winter. J Anim Sci 66, 603-612.

33. Roberts AJ, Paisley SI, Geary TW, et al. (2007) Effects of restricted feeding of beef heifers during the postweaning period on growth, efficiency, and ultrasound carcass characteristics. J Anim Sci 85, 2740-2745.

34. Byrne HA, Tieszen KL, Hollis S, et al. (2000) Evaluation of an electrochemical sensor for measuring blood ketones. Diabetes Care 23, 500-503.

35. Kaneko JJ (1989) Clinical Biochemistry of Domestic Animals, 4th ed. San Diego, CA: Academic Press.

36. Regnault TR, Oddy HV, Nancarrow C, et al. (2004) Glucosestimulated insulin response in pregnant sheep following acute suppression of plasma non-esterified fatty acid concentrations. Reprod Biol Endocrinol 2, 64-73. 
37. Roberts AJ, Geary TW, Grings EE, et al. (2009) Reproductive performance of heifers offered ad libitum or restricted access to feed for a 140-d period after weaning. J Anim Sci 87, 3043-3052.

38. Preston TR \& Leng RA (1987) Matching Ruminant Production Systems with Available Resources in the Tropics and Sub-Tropics. Armidale: Penambul Books.

39. McDowell GH (1983) Hormonal control of glucose homoeostasis in ruminants. Proc Nutr Soc 42, 149-167.

40. Egan AR (1965) Nutritonal status and intake regulation in sheep. Aust J Agric Res 16, 473-483.
41. Waterman RC, Grings EE, Geary TW, et al. (2007) Influence of seasonal forage quality on glucose kinetics of young beef cows. J Anim Sci 85, 2582-2595.

42. Adams DC, Cochran RC \& Currie PO (1987) Forage maturity effects on rumen fermentation, fluid flow, and intake in grazing steers. J Range Manage 40, 404-408.

43. Jarrett IG \& Filsell OH (1960) The effect of diet on acetate tolerance in sheep. Aust J Exp Biol Med Sci 38, 347-353.

44. WRCC (2006) Western US climate historical summaries. http://wwwwrccdriedu/climsumhtml (accessed 24 August 2006). 